DOI: $10.17707 /$ AgricultForest.64.4.18

\author{
Merima MAKAŠ*, Sabahudin BAJRAMOVIĆ, \\ Emil ERJAVEC, Miro REDNAK ${ }^{1}$
}

\title{
ASSESSMENT OF OVERALL SUPPORT TO AGRICULTURE IN BOSNIA AND HERZEGOVINA
}

\section{SUMMARY}

The previous analysis of support to agriculture in Bosnia and Herzegovina $(\mathrm{BiH})$ implied only budgetary transfers without taking account of the support originating from market-price policy measures. The purpose of this paper was to provide, for the first time, an estimate of the total support to the agricultural sector in $\mathrm{BiH}$ as well as the level of protection of producers through the price of agricultural products. This estimate was done using relative support indicators (Ag incentives, Erjavec, OECD), Total transfers to producers (TTP), Nominal rate of protection (NRP) and Nominal rate of assistance (NRA). The computation of these indicators for Bosnia and Herzegovina was done using the original method (Erjavec et all, 2017) suitable for use in countries with underdeveloped agricultural statistics. Percental TTP represents the share of total budget and market-price support to agriculture in the total value of agricultural production, while NRP and NRA indicators show the level of protection of producers through domestic prices of agricultural products. The NRP is defined as the percentage ratio between domestic market price and the reference one, while the NRA represents the difference between gross revenue of agricultural producers calculated based on domestic prices and gross revenue calculated based on reference prices. In this paper, EU reference prices were used for comparison with $\mathrm{BiH}$ domestic prices. The results of the research have shown that there is a difference between $\mathrm{BiH}$ and $\mathrm{EU}$ reference prices indicating the significant protection of $\mathrm{BiH}$ agricultural producers which according to the NRP averages 9 $\%$. On the other hand, the comparison of agricultural producers' revenues calculated based on $\mathrm{BiH}$ prices and revenues calculated based on EU reference prices shows a significantly lower total support - by approximately 4\%. Finally, looking at the share of total transfers within the value of production (TTP), it can be seen that this indicator has almost the same trend as \%NRA, which shows a more significant impact of market price transfer in comparison budget support.

Keywords: support, indicator, Bosnia and Herzegovina, reference price, domestic price

\footnotetext{
${ }^{1}$ Merima Makaš* (corresponding author: m.makas@ppf.unsa.ba), Sabahudin Bajramović, Faculty of Agriculture and Food Sciences, University of Sarajevo, BOSNIA AND HERZEGOVINA; Emil Erjavec, University of Ljubljana, Biotechnical Faculty, SLOVENIA; Miro Rednak, Agricultural Institute of Slovenia, SLOVENIA

Paper is presented on Green Room Sessions - International Conference, Podgorica 2018

Notes: The authors declare that they have no conflicts of interest. Authorship Form signed online.
} 


\section{INTRODUCTION}

By signing the General Framework Agreement for Peace in Bosnia and Herzegovina in late 1995 in Dayton, Bosnia and Herzegovina became a state with two Entities (Federation of $\mathrm{BiH}-\mathrm{FBiH}$ and Republika Srpska - RS) and Brčko District of $\mathrm{BiH}(\mathrm{BD} \mathrm{BiH})$. The complex administrative structure results in the agrarian policy being implemented at several levels. The highest state-level authorities of Bosnia and Herzegovina have limited power in the area of agrarian policy which is reduced to the foreign trade policy responsibilities. Strategic and program documents that are directly related to the programming and development of agricultural policy are the exclusive responsibility of the Entities and Brčko District. In addition to the complex state structure, there is the issue of lack of harmonization between the Entities, and each of the three territorial units has the authority to design, adopt and implement agricultural policy independently of other units, i.e. to implement their own agricultural policy, which ultimately leads to unequal and disadvantageous position of farmers. General assessment of agricultural policy in both BiH entities and Brčko District shows its inconsistency, inadequacy and absence of developed elements of modern public policies (Bajramović et al., 2014, 2015).

Any public policy, including agricultural one, has to have an established policy cycle in order to be successfully implemented. The implementation of this cycle requires a strong analytical support, development of methods, constant monitoring of policy results, democratic discourse and discussion on problems, goals and measures of agricultural policy (OECD, 2010). Getting the effects of agricultural policy to be visible requires a continuous monitoring. Effectiveness of this process could be achieved only through the establishment of a data collection framework which will result in the indicators necessary for further research. The most commonly used method for monitoring the effects of agricultural policy is the one that measures the effect of the policy on the incentives to farmers and their ability to react to those incentives (Josling and Valdes, 2004). In order for these incentives to be comparable it is necessary to translate them into quantitative indicators with focus on prices. There are numerous indicators for monitoring the effects of the policy on the incentives through prices. The simplest and most commonly used is the Nominal Rate of Protection (NRP), which takes into account measures of market price policy and represents the percentage difference between domestic and world market prices. The more comprehensive indicator of the Nominal Rate of Assistance (NRA) implies all the agricultural policy measures that affect the prices of domestic products and is used to compute the level of protection of producers through price. It is defined as the percentage difference between farmer's gross income based on domestic prices relative to income at world prices. The previous analysis of agricultural policy in BiH relied on budgetary support to farmers (BP), without taking into account the market price support (MPS) as the second part of the overall support to agriculture. For this reason, the purpose of this paper is to provide, for the first time, an assessment of overall support to the 
agricultural sector in $\mathrm{BiH}$ using the relative indicator TTP, and by computing the relative indicators NRP and NRA, to show the level of protection of producers through the price of agricultural products and thus provide a comprehensive insight into the agricultural policy of $\mathrm{BiH}$.

\section{MATERIAL AND METHODS}

With regard to the specification and systematization of policy that has impact on agriculture, there is no universal approach to be found in literature. Used in this paper, as an adequate method for assessing the overall agricultural policy, is the OECD PSE/CSE approach which is the standard global method and a sole database that regularly provides agricultural support information comparable for the entire observed period.

The Producer Support Estimate (PSE) is the most commonly used indicator for measuring overall support in agriculture since it has been recognized as a tool for comparing different agricultural policy measures. The OECD PSE approach divides measures into two main groups:

$>$ Policy measures that affect domestic market prices MPS (Market Price Support) cause a gap between the domestic market price and the reference price of a particular product

$>$ Budgetary support measures BP (Budgetary Transfers to Producers) may have a form of actual transfers to producers or a form of reduced budget revenues (e.g. tax incentives to agricultural producers)

Represented mathematically:

$\mathrm{PSE}=\mathrm{MPS}+\mathrm{BP}$

Given that $\mathrm{BiH}$, just like any other developing country, is faced with the problem of statistical data which do not ensure a sufficient level of reliability, for calculating indicators according to the OECD PSE / CSE approach ${ }^{2}$ instead of MPS we used the nominal rate of protection \%NRP to compute estimated rate of producer protection through prices, based on the following formula:

$$
\begin{gathered}
\% N R P i=\frac{P P_{i}}{R P_{i}} * 100-100 \\
\% N R P C=\frac{\sum P P_{i} * Q P_{i}}{\sum R P_{i} * Q P_{i}} * 100-100
\end{gathered}
$$

\footnotetext{
${ }^{2}$ Bosnia and Herzegovina does not have an Agricultural census as the basis for the establishment of the FADN system, the production-consumption balance-sheets of agricultural products, calculating agricultural economic accounts based on OECD methodology
} 
$i=$ individual product

$c=$ aggregation level

$\%$ NRP = Nominal Rate of Protection

$P P=$ Producer price

$R P=$ Reference price

$Q P=$ volume of production

The quantitative estimate of price protection is based on the computation of the percentage ratio between domestic producer's price and reference price for selected product groups caused by measures such as direct measures within the sector or specific interventions by products (e.g. Prices or market regulation, import/export taxes or subsidies), disturbances resulting from macro-economic policies (e.g. Currency exchange rate), interventions in other sectors and nonpolitical factors such as market failure (Erjavec 2017).

NRP is calculated only for representative products and then, based on the share of these products in the total production, it is extrapolated to the level of total production. Representative products are products that make up at least $70 \%$ of the total production value, where the minimum participation of any individual product can not be lower than $1 \%$.

The analysis includes data on producer prices and the total produced quantity for the following group of products: cereals, fruits, vegetables, meat, milk, eggs and honey. Most of the above-mentioned products (product categories) are monitored and there is data evidence registered by BH Agency for statistics, except for meat products. Lack of data in meat production was the main reason why this type of products was assessed. ${ }^{3}$ For comparison with domestic prices, reference EU (world) prices were taken from the OECD website. In principle, the reference world market price should be selected based on the export-import status of a particular product. Simply said, for the products for which the country is a net exporter, average export prices are taken, while in the case of net import products it is the average import prices. Bosnia and Herzegovina has a small and underdeveloped market which makes it a net importer for most of the products that primarily come from the EU market, so this paper's analysis took the EU reference prices for they were considered as most relevant for comparison in the EU aspirant countries (Erjavec, et al, 2003).

In addition to the nominal rate of protection NRP, the indicator of more extensive rate of assistance to producers in the form of nominal rate of assistance - NRA was computed. The indicator represents the increase/decrease in gross income of producers incurred as a result of the implementation of policy measures, i.e. percentage ratio between domestic market price increased by subsidies and reference prices. The NRA actually measures the difference

\footnotetext{
${ }^{3}$ The calculation was made according to the Eurostat method for calculating the meat balance, and on the basis of the data of the BiH Agency for Statistic on the number of live animals and data of the $\mathrm{BiH}$ Foreign Trade Chamber on the number of imported and exported live animals.
} 
between "the incentive price of output" and the reference price (Cahill, Legg, 1990).

Represented mathematically:

For individual level:

For aggregation level:

$$
\% N R A i=\frac{P P_{i} * Q P_{i}+P E_{i}}{R P_{i} * Q P_{i_{i}}} * 100-100
$$

$$
\% N R A c=\frac{\sum P P_{i} * Q P_{i}+\sum P E_{i}}{\sum R P_{i} * Q P_{i}} * 100-100
$$

$\%$ NRA - nominal rate of assistance

$P E=P S E$ BOT budgetary transfer to producers

Given that each Entity has its own agricultural policy, in the quantitative analysis of the budgetary support to agriculture in $\mathrm{BiH}$ we used the aggregated $\mathrm{BiH}$ database on agricultural policy measures (BiH APM database) in which all available information on agricultural policy measures, i.e. budget transfers made in a given year by the relevant entity ministries and agricultural department of the Brčko District Government, were collected. The BiH APM database covers a long period of time, 2002-2015, and data relating to the time series 2010-2015 were used in this paper. ${ }^{4}$

The single APM classification of agricultural budgetary support was created using the EU concept that is based on policy pillars as a basic starting point, combined with the OECD classification (Rednak et al, 2013.). Programming elements of the EU policy (pillars, axes) have been applied at higher aggregation levels, while the OECD criteria have been applied in the case of formation of groups and sub-groups under individual pillars and particularly in the case of defining the lowest level of classification (basic headings). Thus, the APM allows for a rough analysis of budgetary transfers for agriculture also according to the OECD PSE classification and vice versa (Volk et al, 2015).

According to the form of payment, i.e. the conditions for their provision, budgetary payments to the producers according the OECD PSE approach in the APM system, are divided into seven basic groups as follows:

A2 - payments based on output

$\mathrm{B}$ - payments based on input use

C- production required payments based on the current area, number of animals, revenue, income

D- production required payments based on historical rights

E- production not required payments based on historical rights

F - payment based on non-commodity criteria

\footnotetext{
${ }^{4}$ The APM database is the result of the project „Streamlining of agriculutre and rural development policies of SEE countries for EU accession“, available at http://seerural.org/
} 
$\mathrm{G}$ - other types of payment

Estimated market price support in terms of \% NRP, i.e. market price differential MPD along with budgetary support represents total transfer to producers $(\% \mathrm{TTP})^{5}$, or

$$
\begin{gathered}
\% T T P_{c}=\% M P D_{c}+\% P S E B O T_{c} \\
\% M P D c=\frac{\sum M P D_{i}}{\sum V P_{i}} * 100=\frac{\% N R P_{c} * 100}{\% N R P_{c}+100} \\
M P D_{i}=P P_{i}-R P_{i}
\end{gathered}
$$

$\% M P D$-share of the market price differential in the total production value

$\%$ TTP-share of total support in the total production value

By calculating \%TTP we obtained the share of total support to producers which participates in the value of agricultural production.

\section{RESULTS AND DISCUSSION}

Comparison of domestic producers' with EU reference prices shows a significant protection of domestic producers. The highest level of producer protection through price amounting $19.7 \%$ was recorded in 2012, and the lowest amounting $2.3 \%$ in 2014. The reason for this are huge natural disasters that $\mathrm{BiH}$ faced in 2014 and that caused significant damage to production, also reflecting in the total production value and, therefore, the calculation of NRP, NRA and TTP indicators. On average, the \% NRP amounted 12\%, but in recent years there is an evident decrease compared to the initial years of the observed period.

Nominal rate of assistance NRA, i.e. agricultural producer's gross income at domestic prices relative to the income at EU reference prices, varied during the observed period ranging from $26.8 \%$ in 2012 to $8.3 \%$ in 2014 .

During the observed period, level of \%NRA was higher relative to the NRP indicator, but with a considerably smaller share in the total amount of support which indicates a significantly lower protection of producers through budgetary support compared to the price-based one.

The assessment of the total support through \% TTP indicator as a share of total support in the production value has nearly the same trend as \%NRA, precisely because the total level of agricultural support is under the influence of positive/negative market price transfers, whereas budgetary support, due to its amounts, has no significant impact.

\footnotetext{
${ }^{5} \%$ TTP is an indicator that serves as an estimation of producer support aggregates; this is analogous to \% PSE, but not identical. The reason for calculating this indicator using a simplified method instead of \% PSE is poor quality or lack of certain data. Therefore, the numerical values of the two indicators can not be compared directly. However, compared to the PSE calculations performed by OECD similar trend values are shown in some countries.
} 


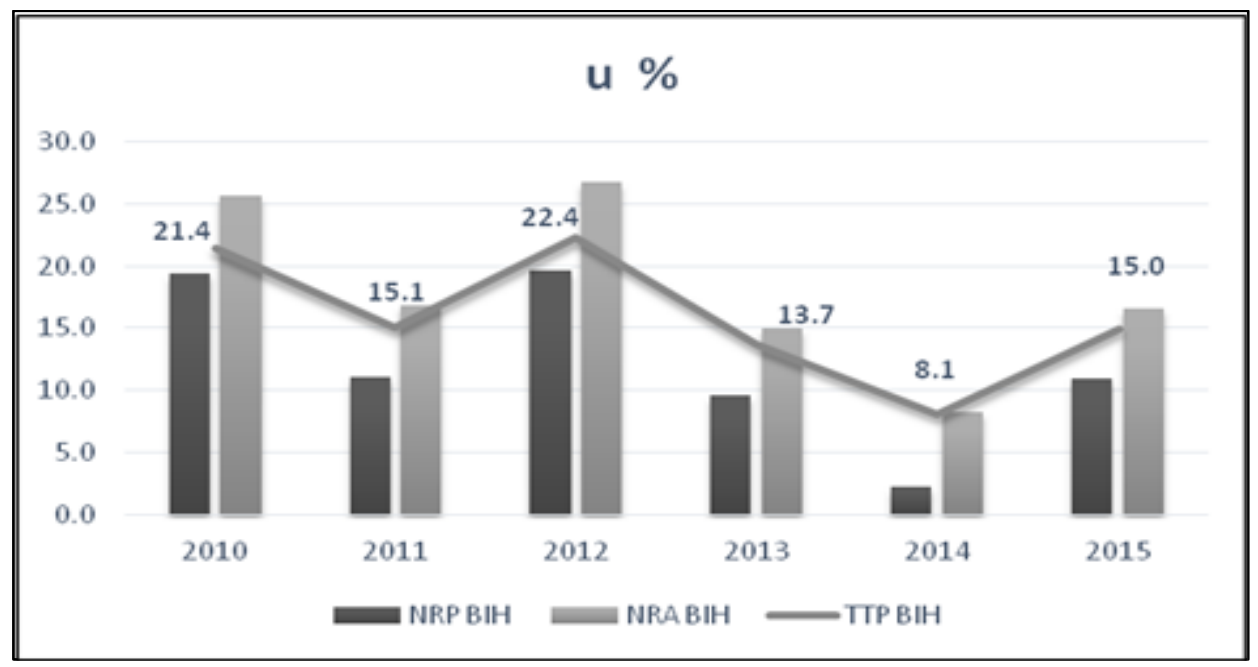

Figure1. Estimated level of protection of agricultural producers in Bosnia and Herzegovina through price and total support to producers within the total value of agricultural production for the period 2010-2015 (own calculations)

\section{CONCLUSIONS}

The estimate of protection of agricultural producers through price and total agricultural support in $\mathrm{BiH}$ through relative indicators represents a significant contribution to the analysis of agricultural policy because, for the first time the market price support was successfully calculated despite the poor quality of statistical data.

When it comes to the protection of agricultural producers, the EU Agricultural Policy is largely based on budgetary support, unlike $\mathrm{BiH}$ where, according to the computation of \%NRP, \%NRA and \%TTP indicators, value of market price measures make up a large part of overall support, indicating that $\mathrm{BiH}$ agricultural policy is still not aligned with the European Union path.

Budget allocations for agricultural support in $\mathrm{BiH}$ as well as their structure are inadequate and insufficient and do not encourage farmers to invest in the production in which they would be more efficient. Measures should therefore be more oriented toward making producers more productive and strengthening their ability to recognize productions with less risky access to the market and ultimately making them more competitive.

\section{REFERENCES}

Bajramović, S., Ognjenović, D., Butković, J. (2015): Bosnia and Herzegovina: Country Agricultural Policy Brief. SWG/IPTS project.

Bajramović, S., Nikolić, A., Butković, J. (2014): Agriculture and Agricultural Policy in Bosnia and Herzegovina, Agricultural Policy and European Integration in SouthEast Europe, FAO, Budapest. 
Cahill, C., Legg, W. (1990): Estimation Of Agricultural Assistance Using Producer And Consumer Subsidy Equivalents: Theory And Practice, OECD Economic Studies

Erjavec, E., Rednak, M., Volk, T.,Turk, J., (2003): The transition from „socialist“ agriculture to the common agricultural policy: the case of Slovenia

Erjavec, E., Volk, T., Rac, I., Kožar, M., Pintar, M., Rednak, M. (2017): Agricultural Support in Selected Eastern European and Eurasian Countries, Post-Communist Economies

Josling, E.T., Valdes, A. (2004): Agricultural Policy Indicators, FAO Commodity and Trade Policy Research Working Paper No4,

OECD (2010): Oecd's Producer Support Estimate And Related Indicators Of Agricultural Support : Concepts, Calculations, Interpretation and Use (The PSE Manual), OECD Publishing Paris

Rednak, M., Volk, T., Erjavec, E., (2013): A tool for uniform classification and analyses of budgetary support to agriculture for the EU accession countries

Volk, T., Rednak, M., Erjavec, E. (2015): Agricultural Policy and European Integration in SouthEast Europe, FAO, Budapest. 